\title{
EFEKTIFITAS AKUPRESUR PADA KENAIKAN BERAT BADAN BAYI
}

\author{
Gladys Galihani Fendristica ${ }^{1}$, Susilawati $^{2}$, Ni Made Armawati ${ }^{3}$ \\ ${ }^{1,2,3}$ Poltekkes Kemenkes Malang Prodi D-IV Kebidanan \\ e-mail:galihanigladys@ymail.com
}

\begin{abstract}
ABSTRAK
Neonatus membutuhkan ASI untuk tumbuh kembang optimal. Selain mampu meningkatkan autoimun bayi sehingga tidak mudah sakit, proses menyusui juga meningkatkan kasih sayang ibu ke bayi. Sedangkan melalui pijatan, ibu mendapatkan kasih sayang dari keluarga. Studi pendahuluan didapatkan estimasi 7 dari 10 ibu tidak menyusui ASI eksklusif, salah satunya dikarenakan produksi ASI kurang. Tujuan penelitian ini adalah mengidentifikasi perbedaan kenaikan berat badan bayi ibu menyusui yang mendapatkan akupresur dengan tanpa akupresur. Penelitian ini menggunakan desain quasi eksperimen dengan rancangan Non-Equivalent Control Group Design. Populasinya adalah ibu hamil berdasarkan hari perkiraan persalinan bulan April 2017 dengan jumlah sampel 32 orang, masing-masing 16 orang kelompok intervensi dan kontrol. Pengambilan sampel dengan accidental sampling. Hasil penelitian didapatkan jumlah kenaikan BB bayi pada kelompok intervensi adalah 16 orang dan kelompok kontrol adalah 9 orang. Hasil uji analisis dengan Independent t-test didapatkan terdapat perbedaan kenaikan berat badan bayi ibu menyusui yang mendapatkan akupresur dengan tanpa akupresur. Dari penelitian diketahui akupresur terbukti dapat meningkatkan produksi ASI dan ikatan antara orangtua dan bayi, yang berdampak pada kualitas ASI juga meningkat. Hal ini otomatis dapat meningkatkan motivasi ibu untuk memberikan ASI eksklusif kepada bayinya.
\end{abstract}

Kata kunci: Akupresur, berat badan bayi, produksi ASI

\section{THE EFFECTIVENESS OF ACUPRESSURE TOWARDS BABY'S WEIGHT GAIN}

\begin{abstract}
Neonates need breast milk to optimally grow and develop. Besides able to increase baby's autoimmune, breastfeeding also improve affection from mother to baby. While through a massage, mother can get affection from family. The preliminary study obtained mothers who did not giving exclusive breast feeding is due to low milk supply. The purpose of this study was to identify differences baby's weight gain between mother who did acupressure and who did not. This study used Non-Equivalent Control Group Design. The population was pregnant women based on due dates in April 2017 with total sample of 32 people divided by 2 group. Samples collected with the method of accidental sampling. The result of the study obtained the number of the baby's weight gain in the intervention group is 16 babies and control group is 9 babies. The results of the analysis test using Independent t-test obtained there are differences baby's weight gain between mother who did acupressure and who did not. The results of the study have shown that acupressure proved to be increasing low milk supply, improve bounding between parents-babies, which also improve the quality of breast milk. This will automatically improve motivation of mother to giving exclusive breast milk to their babies.
\end{abstract}

Keyword: Acupressure, baby's weight gain, low milk supply 


\section{Pendahuluan}

Neonatus merupakan golongan umur yang memiliki risiko gangguan kesehatan paling tinggi. Cakupan Kunjungan Neonatal Pertama atau KN1 merupakan indikator yang menggambarkan upaya kesehatan yang dilakukan untuk mengurangi risiko kematian pada periode neonatal yaitu 6-48 jam setelah lahir yang salah satunya adalah ASI eksklusif (Kementerian Kesehatan RI, 2016). Namun, dari hasil Pemetaan Angka Kematian Bayi per 1.000 Kelahiran Hidup Provinsi Jawa Timur Tahun 2014, Kabupaten Jember menempati posisi kedua yang mencapai 54,72 per 1000 kelahiran hidup. Dalam rangka menurunkan angka kesakitan dan kematian anak, UNICEF dan WHO merekomendasikan sebaiknya anak hanya disusui air susu ibu (ASI) pada usia 0-6 bulan (Dinkesprovjatim 2015). Namun, hasil studi pendahuluan yang dilakukan oleh peneliti di 2 BPM Sumbersari Jember didapatkan estimasi bahwa pada tahun 2016, dari $10 \mathrm{ibu}$ postpartum yang menyusui, 7 dari $10 \mathrm{ibu}$ menyusui, tidak menyusui secara eksklusif karena beberapa faktor. Diantaranya, faktor pertama adalah karena produksi ASI ibu yang kurang pada hari-hari pertama kehidupan bayi dan faktor yang kedua dikarenakan ibu kembali bekerja sehingga fokus ibu untuk menyusui anak menjadi berkurang. Hal ini sesuai dengan hasil penelitian Bangnes (2011) yang menyebutkan faktor-faktor yang mempe- ngaruhi kegagalan pemberian ASI ekskusif antara lain: produksi ASI kurang (32\%), ibu harus kembali bekerja (28\%), terpengaruh iklan susu formula (16\%), faktor nilai sosial budaya (24\%), kurangnya dukungan dari petugas kesehatan (24\%) dan faktor dukungan keluarga (24\%) (Budiyanto et al, 2015). Hal ini didukung oleh Kodrat (2010) yang mengatakan faktor penghambat dalam pemberian ASI adalah produksi ASI itu sendiri. Selain hormon prolaktin, proses laktasi juga bergantung pada hormon oksitosin. Refleks oksitosin ini dipengaruhi oleh jiwa ibu. Jika ada rasa cemas, stress dan ragu yang terjadi, maka pengeluaran ASI bisa terhambat (Mas`adah, 2014). Berbagai macam perawatan telah diterapkan untuk meningkatkan produksi ASI. Dari berbagai jenis non-medis yang ada, salah satu yang dapat digunakan adalah akupresur. Lixin et al (2008) dalam studinya pada efek akupuntur untuk ibu menyusui yang tidak adekuat menunjukkan bahwa metode ini dapat meningkatkan sekresi hormon prolaktin yang mana akan meningkatkan produksi air susu ibu (Esfahani et al, 2015).

Bobak (2005) dalam (Budiadi, et al., 2010) mengungkapkan bahwa faktor psikologis ibu dapat menjalin keterikatan psikologis emosional ibu dan bayi serta merangsang pelepasan endorphin yang menimbulkan vasodilatasi yang meningkatkan aliran darah tubuh sehingga 
tubuh menjadi rileks dan tenang yang sekaligus juga menstimulasi pengeluaran hormon oksitosin yang berperan dalam let down refleks, baiknya refleks ini mengindikasikan lancarnya rang- sangan hormon oksitosin yang mempengaruhi produksi ASI.

Tujuan khusus dari penelitian ini adalah: 1) Mengidentifikasi kenaikan BB bayi baru lahir-usia 12 hari pada ibu menyusui yang tidak diberi akupresur, 2) Mengidentifikasi kenaikan BB bayi baru lahir-usia 12 hari pada ibu menyusui yang diberi akupresur, 3) menganalisis perbedaan kenaikan BB bayi baru lahir-usia 12 hari pada ibu menyusui yang tidak diberi akupresur dan diberi akupresur.

\section{Metode Penelitian}

Penelitian ini merupakan penelitian quasi eksperimen menggunakan rancangan nonequivalent control group design. Penelitian ini bertujuan untuk mengidentifikasi perbedaan kenaikan berat badan bayi ibu menyusui yang mendapatkan akupresur dengan tanpa akupresur. Populasi dalam penelitian ini adalah semua ibu hamil TM 3 berdasarkan hari perkiraan persalinan pada bulan April 2017 di 2 BPM Sumbersari Jember didapatkan sebanyak 32 orang. Sampel pada penelitian ini adalah 32 ibu post partum yang bersalinan pada bulan April 2017 yang menyusui bayi baru lahir-usia 12 hari secara eksklusif tanpa memberikan makanan pendamping apapun di BPM Sumbersari. Besar sampel didapatkan yang dibagi menjadi 16 orang kelompok intervensi dan 16 orang kelompok kontrol. Variabel bebas pada penelitian ini adalah akupresur pada ibu menyusui dan variabel terikat adalah berat badan bayi pada ibu yang diberi akupresur dan berat badan bayi pada ibu yang tidak diberi akupresur. Waktu penelitian dilaksanakan bulan April 2017-Juni 2017

\section{Hasil Penelitian}

Penelitian ini dilakukan pada 32 ibu menyusui yang masuk kriteria inklusi, yang terbagi menjadi 16 orang pada kelompok intervensi dan 16 orang kelompok kontrol. Kelompok intervensi diberikan perlakuan akupresur sedangkan pada kelompok kontrol tidak diberi akupresur dan diukur dengan indikator kenaikan BB bayi sampai usia 12 hari. Data yang terkumpul meliputi data umum dan data khusus. Distribusi data tabulasi silang kenaikan berat badan bayi pada ibu menyusui yang tidak diberi akupresur dan diberi akupresur disajikan dalam Tabel berikut: 
Tabel 1 Hasil Penimbangan Berat Badan Bayi

\begin{tabular}{|c|c|c|c|c|c|c|c|c|}
\hline \multirow{3}{*}{ Kelompok } & \multicolumn{6}{|c|}{ Hasil Penimbangan Berat Badan Bayi } & \multirow{2}{*}{\multicolumn{2}{|c|}{ Total }} \\
\hline & \multicolumn{2}{|c|}{ Turun } & \multicolumn{2}{|c|}{ Tetap } & \multicolumn{2}{|c|}{ Naik } & & \\
\hline & $\mathbf{N}$ & $\%$ & $\mathbf{n}$ & $\%$ & $\mathbf{n}$ & $\%$ & $\mathbf{n}$ & $\%$ \\
\hline Inter vensi & 0 & 0,0 & 0 & 0,0 & 16 & 100 & 16 & 100 \\
\hline Kon trol & 6 & 37,5 & 1 & 6,25 & 9 & 56,25 & 16 & 100 \\
\hline Total & 6 & 18,75 & 1 & 3,125 & 25 & 78,125 & 32 & 100 \\
\hline
\end{tabular}

Tabel 1 menunjukkan hasil penimbangan BB bayi usia 12 hari sebagai indikator produksi ASI diperoleh data bahwa terdapat 16 responden yang diberikan intervensi, BB bayinya mengalami kenaikan (100\%). Sedangkan, pada kelompok kontrol yang tidak diberikan intervensi akupresur, 9 responden $(56,25 \%)$ BB bayi mengalami kenaikan, 1 responden $(6,25 \%)$ BB bayi tetap dan sisanya yaitu 6 responden $(37,5 \%)$ BB bayi mengalami penurunan dalam rentang normal.

Sebelum dilakukan uji t-test sebelumnya dilakukan uji normalitas data dan uji kesamaan varian (homogenitas). Dari hasil data didapatkan hasil p value (Sig) Liliefors pada kelompok 1 sebesar 0,200 dan kelompok 2 sebesar 0,069. Sedangkan hasil p value (Sig) Shapiro Wilk pada kelompok 1 sebesar 0,547 dan kelompok 2 sebesar 0,147. Oleh karena semua hasil $\mathrm{p}$ value (Sig) Shapiro Wilk dan Liliefors bernilai > 0,05, maka kedua kelompok sama-sama berdistribusi normal. Sedangkan, uji Levene's Test didapatkan probabilitas/signifikansi nilai p value $(0,180>0,05)$ maka $\mathrm{H} 0$ diterima. Oleh karena H0 diterima, maka dapat disimpulkan bahwa kedua varian sama. Dengan ini, penggunaan uji t menggunakan Equal Variances Assumed.

Hasil penghitungan spss didapatkan nilai t hitung (Equal Variances Assumed) adalah 6,309 dan nilai $t_{\text {tab }}$ sebesar 2,043. Karena nilai $t_{\text {hit }}$ lebih besar daripada nilai $t_{\text {tab }}(6,309>$ 2,043), berarti terdapat perbedaan bermakna kenaikan BB bayi sebagai indikator produksi ASI antara ibu yang diberi perlakuan akupresur dan ibu yang tidak diberi perlakuan. Selain itu, hasil nilai $\mathrm{p}$ value sebesar 0,000 dimana <0,05. Dengan demikian, H1 diterima karena nilai t yang diperoleh memiliki perbedaan bermakna secara statistik atau signifikan pada probabilitas 0,05 .

\section{Pembahasan}

\section{Kenaikan BB Bayi Pada Ibu Menyusui Yang Tidak Diberi Akupresur}

Hasil penelitian didapatkan bahwa rata-rata kenaikan BB bayi yang tidak diberi perlakuan Akupresur yaitu sebesar 31,25 gram. Teori yang dikemukakan oleh (Sekartini \& Medise, 
2011) menyatakan bahwa rata-rata pertambahan berat badan bayi 20-30 gram/hari. Ketika lahir, badan bayi mengandung banyak cairan tubuh yang hilang dalam beberapa hari. Sebagian besar bayi kehilangan 1/10 dari berat badannya selama 5 hari pertama dan berat badan naik kembali dalam 5 hari berikutnya. Biasanya, pada hari ke-10 berat badan bayi kembali ke berat lahir.

Hasil penelitian Yuliarti (2010) menunjuk- kan dimana lebih dari 80\% kegagalan ibu me- nyusui disebabkan kondisi psikologis ibu. (Rukiyah et al, 2011) menyatakan bahwa stress pada ibu menyusui akan membuat jumlah pro- duksi hormon oksitosin berkurang. Stress meng- hambat reflek let-down karena pelepasan adrena- lin yang menyebabkan vasokontriksi pembuluh darah alveoli. Akibat dari tidak sempurnanya re- flek let-down maka akan terjadi penumpukan air susu di dalam alveoli, sehingga oksitosin sedikit harapannya untuk dapat mencapai target organ mioepitelium.

Berdasarkan teori, jika bayi berusia 12 hari dan menyusu efektif, maka kompensasi kenaikan BB bayi seharusnya sekitar \pm 240-360 gram. Dan rerata kenaikan BB bayi 12 hari tersebut termasuk kurang bila dibandingkan dengan teori. Bila frekuensi dan lama penyusuan, posisi menyusui, nutrisi ibu, berat lahir bayi dan isapan bayi yang merupakan beberapa faktor penting yang memengaruhi produksi ASI sudah baik, maka stress dan lelah yang dirasakan ibu yang menyusui karena adaptasi setelah melahirkan, dapat menjadi salah satu penyebab yang menghambat produksi ASI. Reflek let-down menjadi tidak sempurna sehingga bayi yang masih merasa haus menjadi tidak puas saat disu- sui. Ketidakpuasan ini akan menjadi tambahan stress bagi ibu karena merasa anaknya tidak kenyang dan rewel saat disusui.

\section{Kenaikan BB Bayi Pada Ibu Menyusui Yang Diberi Akupresur}

Hasil penelitian didapatkan bahwa rata-rata kenaikan berat badan bayi yang diberi perlakuan Akupresur yaitu sebesar 484,4 gram. Dari data diketahui bahwa dari 16 responden yang diberikan perlakuan akupresur, seluruhnya menyatakan merasakan efek dilakukan akupresur. Hal ini diperkuat hasil data bahwa 16 res- ponden yang diberikan akupresur merasakan rasa nyaman/rileks setelah dilakukan akupresur.

Akupresur dapat membantu meningkatkan rasa rileks ibu, sesuai dengan pernyataan (Garret et al, 2003 dalam Apriany, 2010; Saputra, 2000) yang menyatakan Acupressure points for lactation dapat meningkatkan perasaan rileks pada ibu postpartum dan membantu mengurangi rasa ketidaknyamanan. Yuliarti (2010) juga mengatakan peran orang terdekat juga sangat dibutuhkan dalam pemberian ASI eksklusif terutama suami. 
Teori yang dikemukakan oleh (Sekartini \& Medise, 2011) sesuai dengan data rata-rata kenaikan BB yang diperoleh. Hasil kenaikan BB bayi yang diukur tersebut didapat setelah ibu menyusui diberi perlakuan Akupresur selama 12 hari berturut-turut.

Akupresur mudah diterapkan oleh masyarakat karena hanya menggunakan media tangan untuk memijat. Pijatan yang dilakukan dapat mengurangi ketegangan, relaksasi otot tubuh dan memberikan rasa nyaman pada ibu. Hal ini berarti secara psikis akan memberikan dampak positif dengan turunnya tingkat stress.

Selain itu, keluarga sebagai salah satu faktor penting dalam mendukung keberhasilan menyusui secara eksklusif juga dapat berperan dalam membantu ibu. Keluarga, terutama suami dapat berperan aktif membantu ibu untuk melakukan pijatan dan menciptakan bounding sebagai adaptasi peran orangtua dan bayi. Dukungan, perhatian dan membantu memijat sebagai bentuk peran aktif suami merupakan kombinasi yang mampu mengatasi perasaan stress, lelah maupun perubahan psikologis periode postpartum lain yang mungkin muncul sehingga mengganggu proses menyusui eksklusif.

\section{Analisa Perbedaan Kenaikan BB Bayi Pada Ibu Menyusui Yang Tidak Diberi Akupresur dan Diberi Akupresur}

Hasil penelitian didapatkan bahwa rata-rata kenaikan berat badan bayi yang tidak diberi perlakuan Akupresur yaitu sebesar 31,25 gram. Dan rata-rata kenaikan berat badan bayi yang diberi perlakuan Akupresur yaitu sebesar 484,4 gram.

Menurut Chung, Hung, Kuo \& Huang (2003) dalam (Rahayu etal, 2015), titik yang akan distimulasi dengan pijat akupresur adalah tangan, kaki dan titik lokal payudara yang akan membantu jumlah ASI secara maksimal. Akupresur juga dapat merangsang pelepasan oksitosin dari kelenjar hipofisis yang secara langsung merangsang produksi ASI. Karena itu akupresur dapat merangsang acupoints dan dapat digunakan untuk membantu pengeluaran ASI. Gach dalam (Sholeh, 2006) juga menyatakan bahwa pijatan akupresur akan menstimulasi peningkatan morphin tubuh yaitu endorfin. Hal tersebut didukung oleh teori gate control, di mana dalam teori tersebut menjelaskan bahwa perangsangan pada suatu titik acupoint pada suatu jalur meridian akan diteruskan oleh serabut saraf A-Beta berdiameter besar menuju saraf spinal yang kemudian dalam medulla spinalis terdapat subtansi gelatinosa bekerja sebagai gate control sebelum diteruskan oleh serabut saraf aferen menuju sel-sel transmisi, sel transmisi menyalurkan ke sistem saraf pusat dengan menurunkan rasa ketidaknyamanan (Hakam et al, 2009). 
Harga yang murah, mudah dipelajari dan non-infasif (tindakan medis yang tidak membu- tuhkan tubuh dimasuki) adalah beberapa keuntungan dari akupresur.

Suasana yang nyaman, tenang dan rileks akan mendatangkan emosi positif yang dapat meningkatkan sekresi neurotransmiter endorphin melalui POMC yang berfungsi sebagai penghilang rasa sakit sehingga semakin mening- katkan reflek let down dan meningkatkan jumlah hormon prolaktin dan oksitosin.

Selain berdampak pada peningkatan produksi ASI, dengan adanya bounding antara ibu dan bayi, juga akan berdampak positif terhadap bayi. Bila ibu merasa nyaman dan tenang maka bayi juga ikut tenang sehingga proses menyusui juga menjadi nyaman dan menyenangkan. Bayi mendapatkan ASI yang cukup dari ibu sehingga BB bayi meningkat, ibu juga akan jauh lebih tenang dan bahagia mengetahui BB bayi meningkat, sehingga proses menyusui menjadi moment yang menyenangkan dan berkesan bagi ibu.

\section{Kesimpulan}

Terdapat perbedaan rata-rata kenaikan $\mathrm{BB}$, rata-rata kenaikan penimbangan $\mathrm{BB}$ bayi usia 12 hari pada kelompok yang tidak dilakukan akupresur adalah sebesar 31,25 gram, sedangkan rata-rata kenaikan penimbangan BB bayi pada kelompok ibu yang dilakukan akupresur adalah sebesar 484,4 gram.

\section{Saran}

Diharapkan bagi petugas kesehatan dapat mempelajari akupresur sebagai salah satu alternatif untuk meningkatkan produksi ASI dan dapat diujicoba dan diajarkan kepada ibu menyusui, mengingat banyak manfaat yang bisa didapatkan. Diharapkan tetap dilakukan pengembangan penelitian berkelanjutan dan hasil penelitian ini dapat digunakan sebagai informasi untuk bahan penelitian sejenis dengan jumlah sampel yang lebih besar, dalam waktu yang lebih lama dan dapat mengontrol faktor-faktor lain yang mempengaruhi produksi ASI ibu menyusui.

\section{Daftar Pustaka}

Amelia, C.R. (2014). Perbedaan Efektifitas Antara Metode Tens Dengan Metode Akupresur Terhadap Penurunan Intensitas Dysmenorrhea Pada Remaja Di Asrama Putri Jurusan Kebidanan Politeknik Kesehatan Kemenkes Malang. Malang: Politeknik Kesehatan Kemenkes Malang. 
Astuti, et al. (2015). Asuhan Kebidanan Nifas \& Menyusui. Jakarta: PT Gelora Aksara Pratama.

Bahiyatun. (2009). Buku Ajar Asuhan Kebidanan Nifas Normal. Jakarta: EGC.

Budiatiet al. (2010). Peningkatan Produksi ASI Ibu Nifas Seksio Sesarea Melalui Pemberian Paket "Sukses ASI”Jurnal Keperawatan Indonesia, 13(2).

Budiyanto et al. (2015). Hubungan Ketersediaan Fasilitas Penunjang Terhadap Keberhasilan Pemberian ASI Eksklusif Pada Ibu Yang Bekerja Sebagai Tenaga Kesehatan. Jurnal Ilmiah Keperawatan 11(1), pp.6-18.

Dinas Kesehatan Kabupaten Jember. (2014). Profil Kesehatan Kabupaten Jember Tahun 2014. Jember: Dinas Kesehatan Kabupaten Jember.

Dinkesprovjatim. (2015). Profil Kesehatan Provinsi Jawa Timur Tahun 2014. Surabaya:Dinkesprovjatim.

Esfahani et al. (2015). Effect Of Acupressure On Milk Volume Of Breastfeeding Mothers Referring To Selected Health Care Centers In Tehran. Iranian journal of nursing and midwifery research 20(1), pp.7-11.

Fitria, Sri Yuni. (2010). Efektifitas Inisiasi Menyusu Dini Terhadap Peningkatan Produksi ASI Di Klinik Bersalin Mariani. Medan : Universitas Sumatera Utara.

Hartono, Radyanto Iwan Widya. 2012. Akupresur Untuk Berbagai Penyakit I. Yogyakarta: Rapha Publishing.

Hia, Deoserina. (2015). Pemberian Air Susu Ibu (ASI) Eksklusif Pada Masyarakat Di Desa Mazingo Tanoseo Kecamatan Hiliduho Kabupaten Nias Tahun 2015. Medan: Universitas Sumatera Utara.

Hidayat, A.Alimul Aziz. (2008). Pengantar Ilmu Kesehatan Anak untuk Pendidikan Kebidanan. Jakarta: Salemba Medika.

Judarwanto, W. (2016). Klinik ASI Laktasi. Available at: https://asilaktasi.com/2016/02/22/pertumbuhan-normal-pada-bayi-dengan-asi-ekslusif/ [Accessed December 29, 2016].

Karin Cadwell \& Cindy Turner Maffei. (2011). Manajemen Laktasi: Buku Saku (Terjemahan oleh Estu Tiar). Jakarta: EGC.

Kemenkes RI. (2012). Lokasi Titik Akupresur Untuk Wanita.Palembang : Direktorat Jenderal Bina Gizi dan KIA Kemenkes RI. (2014). Panduan Akuprresur Mandiri Bagi Pekerja di Tempat Kerja.Jakarta : Direktorat Jenderal Bina Gizi dan Kesehatan Ibu dan Anak.

. (2014). Situasi dan Analisis ASI Eksklusif. Jakarta Selatan: Pusat Data dan Informasi Kementerian Kesehatan RI. . (2016). Profil Kesehatan Indonesia 2015. Jakarta: Kementerian Kesehatan RI.

Pusat Pendidikan dan Pelatihan Tenaga Kesehatan. 2014. Buku Ajar Kesehatan Ibu dan Anak, Jakarta Selatan: Kementerian Kesehatan RI. 
Kurnia, A. (2013). Pijat Refleksi Untuk Melancarkan ASI. Available at: http://pojokmungil.com/pijat-refleksi-untuk-melancarkan-asi/ [Accessed December 30, 2016].

Lowe, L.A. (2012). Ana-Med Acupuncture: AcuPressure Points.Available at: http://www.ana-med.co.nz/ [Accessed December 29, 2016].

Lynch, C. (2015). Lactation Insufficiency Solutions Through Chinese Medicine.Available at: http://goldencraneacu.blogspot.co.id/2015/08/lactation-insufficiency-solutions.html [Accessed December 29, 2016].

Mas’adah. (2014). Teknik Meningkatkan Dan Memperlancar Produksi ASI Pada Ibu Post Sectio Caesaria.Jurnal Poltekkes Kemenkes Mataram, pp 1-10.

Monika, F.B. (2014). Buku Pintar ASI dan Menyusui. Jakarta Selatan: Noura Books (PT Mizan Publika).

Mukherjee, B. (2015). Acupressure for New Mothers-Points to Heal Postpartum Issues. Available at: http://www.modernreflexology.com/acupuncture-for-postpartumdepression/ [Accessed December 29, 2016].

Muliani, R.H. (2013). Perbedaan Produksi ASI Sebelum Dan Sesudah Dilakukan Kombinasi Metode Massase Depan (Breast Care) Dan Massase Belakang (Pijat Oksitosin) Pada Ibu Menyusui 0-3 Bulan Di Wilayah Kerja Puskesmas Kesamiran Kabupaten Tegal. Jurnal Kampus Terpadu Ngudi Waluyo, pp 1-10.

Murray, S.M. (2015). Acupuncture To Increase Lactation Postpartum. Chinese Medicine Acupuncture Clinical Studies 6 February, pp 1-7.

Notoatmodjo, S. (2005). Metodologi Penelitian Kesehatan. Jakarta: Rineka Cipta. . (2010). Metodologi Penelitian Kesehatan. Jakarta: Rineka Cipta.

Nursalam. (2009). Konsep dan Penerapan Metodologi Penelitian Ilmu Keperawatan. Jakarta: Salemba Medika.

Poole et al. (2014). The Facts About Universal Medicine. Esther Rockett Byron Bay Acupuncturist - a professional with a questionable understanding of anatomy. Available at: $\quad$ http://universalmedicinefacts.com/esther-rockett-byron-bay-acupuncturist-aprofessional-with-a-questionable-understanding-of-anatomy/ [Accessed January 23, 2017].

Rahayuet al. (2015). Produksi ASI Ibu Dengan Intervensi Acupresure Point For Lactation Dan Pijat Oksitosin. Jurnal Ners 10, pp 9-19.

Riduwan \& Akdon. (2009). Rumus dan Data dalam Analisis Statistika. Bandung: Alfabeta.

Rini Sekartini \& Bernie Endyarni Medise. 2011. Buku Pintar Bayi. Jakarta: Pustaka Bunda.

Rusdiatin \& Maulana. (2007). Pengaruh Pemberian Teknik Akupresur Terhadap Tingkat Nyeri Persalinan Kala 1 Di Rumah Sakit Rajawali Citra Potorono Banguntapan Bantul. Yogyakarta.

Sari, R. (2016). Faktor-faktor yang Memengaruhi Pemberian ASI Eksklusif di Wilayah Kerja Puskesmas Bandaraya Banda Aceh Tahun 
Soetjiningsih. (2009). ASI : Petunjuk Untuk Tenaga Kesehatan. Jakarta: EGC.

Sriwahyuni, E. (2013). Hubungan Inisiasi Menyusu Dini, Asupan Gizi Saat Hamil Dan Tingkat Kecemasan Dengan Kecepatan Produksi ASI Ibu Pascapersalinan Di Bidan Praktek Mandiri Medan Tahun 2013. Medan: Universitas Sumatera Utara.

Sugiyono. (2009). Metode Penelitian Pendidikan: Pendekatan Kuantitatif, Kualitatif dan $R \& D$. Bandung: Alfabeta 